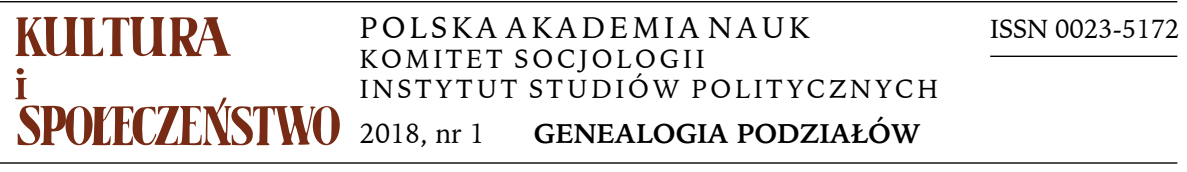
A $\mathrm{R}$
R $\quad \mathrm{T} \quad \mathrm{Y}$
$\begin{array}{llll}K & U & \mathbf{L} & \mathbf{Y}\end{array}$
I
$\begin{array}{llllllll}\mathbf{R} & \mathrm{O} & \mathrm{Z} & \mathbf{P} & \mathbf{R} & \mathrm{A} & \mathrm{W} & \mathrm{Y}\end{array}$

ANTONI Z. KAMIŃSKI

Instytut Studiów Politycznych PAN

\title{
ETOS DWORU I „LUDZI DOBRZE WYCHOWANYCH”: EPITAFIUM DLA INTELIGENCJI*
}

\begin{abstract}
"Jesteśmy wszak świadomi, że przywiązanie do kraju, języka, kultury, tradycji historycznej, a nade wszystko do Rzeczypospolitej i jej symboli, stanowi samo w sobie moralną i duchową wartość, a ponadto konstytuuje wspólnotę sentymentów, która jest trudną do zastąpienia podstawą demokracji politycznej".
\end{abstract}

Jerzy Jedlicki, Oblicza polskiego patriotyzmu

\section{WSTĘP}

Rozważania te nawiązują do znanego eseju Józefa Chałasińskiego o społecznej genealogii polskiej inteligencji ${ }^{1}$. Widział on $\mathrm{w}$ inteligencji efekt rozpadu społeczeństwa feudalnego, warstwę, która w XIX wieku przejęła po szlachcie rolę $\mathrm{W}$ społeczeństwie wiodącą. $\mathrm{W}$ tej roli okazała się, jego zdaniem, ważna

Adres do korespondencji: kaminski@isppan.waw.pl

* Za cenne uwagi i sugestie dziękuję Piotrowi Chmielewskiemu, Joannie Kurczewskiej, Ince Słodkowskiej, Włodzimierzowi Wesołowskiemu i Rafałowi Wierzchosławskiemu, Pawłowi Solochowi, uczestnikom mojego seminarium w ISP PAN, a także osobom, z którymi wielokrotnie rozmawiałem na podobne tematy. Odpowiedzialność za wyrażone w artykule poglądy ponosi wyłącznie autor.

${ }^{1}$,Z punktu widzenia socjologicznego o istnieniu inteligencji jako warstwy społecznej decyduje [...] forma życia zbiorowego inteligentów, która by w inteligenckiej kulturze i inteligenckiej warstwie pełniła podobną rolę, co folwark-dwór wśród szlachty, a wieś-sąsiedztwo wśród chłopów". Tym, co charakteryzuje inteligencję, jest swoista zasada środowiskowego doboru: „dobre towarzystwo oto podstawowa instytucja inteligencji polskiej" (Chałasiński 1946, s. 20-21). 
dla przetrwania idei polskiej państwowości. Pod innymi względami była, jak pisał, warstwą pasożytniczą i anachroniczną, nieprzydatną, by sprostać wymogom narzuconej przez kapitalizm „rywalizacji narodów w wyścigu do wspólnych wielkich ogólnoludzkich celów" (Chałasiński 1946, s. 13) 2 . Chałasińskiego w opisie inteligencji inspirowały koncepcje jego mistrza, Floriana Znanieckiego, nade wszystko typ osobowości społecznej - „ludzi dobrze wychowanych" (Znaniecki 1974).

Przy całej przenikliwości i błyskotliwości analiz Społeczna genealogia inteligencji polskiej jest pamfletem na inteligencję jako warstwę społeczną. Pod pozorem obiektywizmu łatwo $\mathrm{w}$ nim bowiem dostrzec osobiste emocje inteligenta pierwszej generacji, który szukał swego miejsca w nie całkiem bliskim mu świecie. Jest to zarazem wizja zaangażowanego obywatela, pragnącego widzieć sukces kulturalny i polityczny swojej ojczyzny. Z tej perspektywy Józef Chałasiński jawi się jako kontynuator wielkiej tradycji krytyków-wychowawców kolejnych pokoleń Polaków, począwszy od Andrzeja Frycza Modrzewskiego i Piotra Skargi, przez pisarzy Oświecenia i pozytywizmu, historyków warszawskich i krakowskich spierających się o źródła upadku Rzeczypospolitej, aż po Adolfa Bocheńskiego i środowisko paryskiej „Kultury”, a także wielu innych. Była to tradycja obywatelska w rozumieniu T. H. Marshalla (1951, s. 151): „Obywatelstwo wymaga bezpośredniego poczucia uczestnictwa we wspólnocie wynikającego z lojalności wobec cywilizacji będącej jej wspólnym dziedzictwem. Jest to lojalność wolnych ludzi, posiadających prawa i chronionych przez prawo. Ich rozwój jest stymulowany przez wysiłek, $z$ jakim prawa te zdobyto i satysfakcję płynącą z ich zdobycia".

Twórcy ci zajmowali różne stanowiska poznawcze, zależnie od epoki, miejsca w strukturze społecznej, osobistych losów i ideologicznych nastawień. Łączyła ich troska o Polskę, przyszłość kraju, kondycję jego mieszkańców — odpowiedzialna, obywatelska postawa. Ich aktywność wykuwała i rozwijała polską tożsamość narodową, przetwarzając w każdym pokoleniu to, co najcenniejsze $\mathrm{w}$ polskiej tradycji i historii i co najbardziej potrzebne do sprostania wyzwaniom współczesności. Nie była to sytuacja w ówczesnym świecie wyjątkowa.

Wraz z drugą wojną światową znika polska inteligencja jako stan. Była przedmiotem celowej eksterminacji przez hitlerowskich i sowieckich okupantów: masowych wywózek na Syberię w latach 1939-1941, mordów, których symbolem stał się Katyń; na terenach pod niemiecką okupacją jej losy znaczyły Piaśnica i Palmiry, aresztowanie krakowskiej profesury i rozstrzelanie profesorów lwowskich, obozy koncentracyjne, gehenna powstania warszawskiego i eksterminacja Polaków pochodzenia żydowskiego. Część z tych, którzy prze-

2 Chałasiński w odniesieniu do inteligencji konsekwentnie używa terminu „warstwa”, chociaż z kontekstu wynika, że właściwsze byłoby tu pojęcie „stan” w rozumieniu Maksa Webera (2002, s. 231-232). 
żyli wojnę, znalazła się na emigracji. Okres powojenny w PRL też nie był łaskawy dla resztek inteligencji - dla komunistycznego państwa patriotyczny etos inteligencji stanowił żywotne zagrożenie. Zastąpili ją ludzie w pełni zależni od ustanowionej przez Kreml władzy komunistycznej. Warunkiem stabilności rządów totalitarnych jest atomizacja społeczeństwa ${ }^{3}$. Inteligencja — jako fenomen kulturalny - uległa więc biologicznemu i materialnemu wyniszczeniu w wyniku wojny oraz świadomej polityki reżimu komunistycznego. Przypomina to uwagę Alexisa de Tocqueville (1970, s. 166) o wytępieniu szlachty przez Rewolucję Francuską: „nic nie zdołało jej całkowicie zastąpić, a ona sama nigdy się już nie odrodzi; może odzyskać tytuły i dobra, ale nie odzyska duszy swoich przodków".

Miejsce inteligencji zajęli ludzie nowi, wykształceni po wojnie, wywodzący się z różnych środowisk, reprezentujący różne tradycje kulturowe. Wynikło to po części z potrzeby wypełnienia powojennej „próżni demograficznej”, a po części z realizowanej przez władze komunistyczne rewolucji ustrojowej (Ossowski 1968). Przerwana została ciągłość rozwoju kulturalnego Polski. Nowa „warstwa wykształcona" musiała budować własne miejsce w społeczeństwie. Formowaniu się nowej elity umysłowej towarzyszy brak kulturalnego osadzenia i niepewność statusu. Poszukiwanie nowej tożsamości poszło w dwóch kierunkach: szukania inspiracji na zewnątrz, we współczesnych wzorach zachodnich, przy odrzuceniu „tutejszości”, oraz koncentracji wewnątrz, czyli skupienia się na obronie wyimaginowanej „oblężonej twierdzy”. Rozwój historyczny przerwany przez zabory, a po krótkim okresie niepodległości wojenna trauma spowodowały, że tożsamość narodowa nie mogła się ugruntować.

\section{KOSMOPOLITYZM — INTERNACJONALIZM; PATRIOTYZM — NACJONALIZM}

Należy rozróżnić między kosmopolityzmem a internacjonalizmem oraz między patriotyzmem a nacjonalizmem ${ }^{4}$. Zdaniem Leszka Kołakowskiego (2009, s. 158-159): „nie ma sprzeczności nieuleczalnej między nastawieniem kosmopolitycznym w tych wszystkich dziedzinach życia, gdzie jest ono dobrze uzasadnione, a przywiązaniem do własnego narodowego dziedzictwa". Dostrzegał on zagrożenia związane $z$ zasklepieniem się $\mathrm{w}$ tożsamości narodowej i konkludował: „potrzebujemy tedy potężnych sił duchowych kosmopolitycznych, które w możliwie znacznym stopniu narzucałyby wędzidło etnicznym zaślepieniom ${ }^{5}$. „Obywatel świata” jest zawsze potrzebny.

\footnotetext{
${ }^{3} \mathrm{Na}$ temat komunizmu jako projektu ustroju zob. Kamiński 1992.

${ }^{4}$ Pierwszą parę pojęć wprowadza na przykład Jerzy Jedlicki (1996. s. 3); a drugą Karol Wojtyła (Jan Paweł II 2005, s. 73): „Charakterystyczne dla nacjonalizmu jest [...] to, że uznaje tylko dobro własnego narodu i tylko do niego dąży, nie licząc się z prawami innych. Patriotyzm natomiast, jako miłość ojczyzny, przyznaje wszystkim innym narodom takie same prawo jak własnemu [...]".

5 Tony Judt (2013, s. 172) pisał o środkowo- i południowoeuropejskich emigrantach w Paryżu po drugiej wojnie światowej: „[... byli] dziedzicami należących do przeszłości kosmopolitycznych
} 
„Internacjonalizm”, w przyjętym tu rozumieniu, stanowi skrajność, która polega na odrzuceniu tożsamości narodowej i zastąpieniu jej abstrakcją, która sprowadza się do moralnego nihilizmu. „Totalitaryzm zniknął, gdyż zniknęły terror i przemoc fizyczna. Pozostała jednak ta sama ideologia, która jest zdecydowana narzucić się nam w inny sposób. [...] Inaczej mówiąc, chodzi o usunięcie wszelkich korzeni" (Delsol 2017, s. 93). Internacjonalizm jest dziedzictwem komunizmu, który utracił podstawę w teorii. Jednak ideologia ta stanowi dla cywilizacji Zachodu nie mniejsze zagrożenie od nacjonalizmu. Kosmopolityzm łatwo pogodzić z patriotyzmem, skrajności w postaci nacjonalizmu i internacjonalizmu pogodzić się nie dadzą - ani między sobą, ani też z patriotyzmem czy kosmopolityzmem.

Polskie życie publiczne opanowały w znacznej mierze obie skrajności. „Internacjonaliści" szukają wzorów w modnych, z reguły lewicowych, trendach artystycznych i intelektualnych Zachodu i tam lokują swój układ odniesienia. Towarzyszy temu często postawa odcinania się od „polskości”, to jest od społeczeństwa $z$ jego tradycją i historią ${ }^{6}$. W ich percepcji społeczeństwo jest zacofane, ksenofobiczne i antysemickie, a pielęgnowanie narodowej tradycji jest szkodliwe, bo „państwo narodowe” i tak wkrótce przejdzie do lamusa historii. W reakcji „narodowa kontrelita” wartości narodowe afirmuje, choć czasem podobnie surowo, $z$ innych powodów, ocenia historię Polski, widząc w niej groźbę anarchii i słabości wobec zewnętrznego zagrożenia 7 . Jest to źródło obsesji na punkcie zagrożeń, a jak ich nie ma, to się je sztucznie tworzy. Sprostanie zagrożeniom wymaga silnego państwa $-z$ tym łatwo się zgodzić. Ale silne państwo w ujęciu narodowców sprowadza się do centralizacji decyzji, skupienia wokół przywódców politycznych i arbitralności władzy. Nie jest to państwo silne instytucjami.

Obie orientacje współistnieją, wzajemnie się nie uznając, szermując wobec siebie inwektywami. W ten sposób uzasadniają nawzajem swoje istnienie: jedna jest niezbędna do istnienia drugiej. Pojawił się „syndrom myślenia

[...] rubieży Europy, w których Niemcy, Żydzi, Grecy, Włosi, Polacy, Francuzi i przedstawiciele innych jeszcze nacji przez długie lata żyli obok siebie w twórczej dysharmonii”.

${ }^{6}$ Wywiad udzielony przez prof. Jana Grabowskiego „Gazecie Wyborczej” (23 marca 201 ) nosi tytuł Pomagaliśmy Niemcom zabijać Żydów. Tytuł odpowiada treści. Grabowski, podobnie jak Jan Tomasz Gross, z lubością nadużywa dużego kwantyfikatora. Nasuwa to pytanie, czy wszyscy pomagali? Jeżeli nie, to kto pomagał? Może sam profesor Grabowski, skoro używa pierwszego przypadku liczby mnogiej? Udział w populacji „aktywnych pomocników” w eksterminacji ludności żydowskiej, jak sądzę, był niewielki, chociaż ich rola w zbrodni była znacząca, bo podnosiła skuteczność działań okupanta w stosunku do ofiar oraz ryzyko związane z niesieniem Żydom pomocy. Dlaczegóż to Polacy właśnie mają być narodem złożonym z samych nieskazitelnych aniołów? Gdzie znaleźć taki naród?

7 „Stawianie znaku równości między wolnościowymi aspiracjami Polaków a dążeniami anarchicznymi oraz wywodzenie tych dążeń ze smutnego dziedzictwa anarchii szlacheckiej charakteryzowało w okresie przedwojennym zarówno prawicę endecką szermującą ideą "silnego narodu», jak i prawicę sanacyjną lansującą hasło "silnego państwa»" (Walicki 2009, s. 345-346). 
grupowego" (Chmielewski 2016, s. 248), który uniemożliwia merytoryczną dyskusję między wyznawcami odmiennych poglądów. Opanowanie przestrzeni publicznej przez plemienny spór prowadzi do upadku tak ważnej w polskiej kulturze politycznej tradycji obywatelskości oraz do rozkładu życia publicznego ${ }^{8}$.

Takie okresy pojawiały się w przeszłości. Jednak istniały środowiska pełniące rolę łącznika między sprzecznymi orientacjami intelektualnymi. Taką funkcję pełniła inteligencja, z jej formami życia towarzyskiego, na które utyskiwał Chałasiński. Na przełomie wieków XIX i XX inteligencja była w społeczeństwie warstwą wiodącą i współtwórcą etosu narodowego. Jednym $z$ celów tych rozważań jest próba wskazania na te wartości republikańskiej tradycji etosu „szlachecko-inteligenckiego”, które — zdaniem autora — zasługują na uwagę.

„Historia — jak zauważył Vilfredo Pareto — jest cmentarzyskiem elit”. Każda $z$ nich pozostawiła po sobie pewne wartości. Narody, które nie potrafią właściwie ich wyselekcjonować i pielęgnować, marnie kończą.

\section{ETOS NARODOWY I KRYTERIUM PRAWDY}

Dla Marii Ossowskiej (1986, s. 5) ethos to: „[...] styl życia jakiejś zbiorowości, ogólna [...] orientacja jakiejś kultury, przyjęta przez nią hierarchia wartości bądź formułowana explicite, bądź dająca się wyczytać z ludzkich zachowań". Przyjmując podobne rozumienie tego pojęcia, odnoszę je do zagadnienia narodowej tożsamości, owego mitu założycielskiego narodowej wspólnoty. Etos narodowy pozwala jej określić swą tożsamość, wyznaczyć granicę ze światem zewnętrznym $\mathrm{w}$ sferze wyznawanych wzorów i wartości. Rzeczywiste zachowania ludzi często odbiegają od norm w nim zawartych. Etos, mając charakter normatywny, określa ideał, do którego ludzie powinni dążyć, choć nie zawsze to robią.

Naród jest wspólnotą terytorialną, na ogół posiadającą własną państwowość, choć nie jest to warunek niezbędny; a jego granice nie zawsze się w pełni pokrywają z granicami wyznaczanymi przez wspólnotę kultury. Terytorium zamieszkiwane przez naród jest Ojczyzną ${ }^{9}$. „Ojczyzna - pisała Anna Pawełczyńska (2010, s. 55) - to ludzie i zagospodarowana przez nich ziemia oraz utrwalony dorobek duchowy i materialny. To także pamięć historyczna, która przechowuje wspólnotową świadomość. Jest ona właściwością ludzkiej zbioro-

\footnotetext{
${ }^{8}$ Bartłomiej Różycki i Amelie Zima (2017, s. 188-189) słusznie zauważyli, że konfrontacja różnych narracji pamięciowych sama w sobie nie musi zagrażać funkcjonowaniu systemu społeczno-politycznego: „Sytuacja wygląda inaczej w przypadkach skrajnych, gdy dana narracja aspiruje do monopolu na funkcjonowanie w pamięci zbiorowej i dąży do eliminowania wszelkiej konkurencji".

${ }^{9}$ Wyjątkiem jest naród żydowski, który przez blisko dwa tysiące lat istniał w rozproszeniu, żyjąc mitem Ojczyzny.
} 
wości należącej do kolejnych pokoleń. Ojczyznę cementuje tradycja, na którą składa się dokonany przez ponadpokoleniową wspólnotę wybór wartości i postaw. Podobnego wyboru dokonuje każda prawie rodzina, przekazując opowieści o przodkach i tworząc własną tradycję rodzinną".

Związek między ideą etosu narodowego, tradycji a nauką historii, rozumianą jako badanie wydarzeń historycznych i związków między nimi, jest luźny (Szacki 2011, s. 235-250). Etos nie poddaje się wprost weryfikacji zawartej w nim prawdy, lecz przede wszystkim szeroko pojętej ocenie słuszności i przydatności jako podstawa integracji społecznej. Nie jest to jednak wybór całkowicie oderwany od rzeczywistości historycznej (Rieff 2017, s. 35). Szmalcownicy mają miejsce w historii Polski czasów drugiej wojny światowej, ale nie są częścią narodowego etosu ${ }^{10}$. Jest nią zaś ogromny wysiłek narodu, na wszystkich polach, w wojnie z Niemcami. Etos narodowy jest wynikiem procesu zbiorowego wyboru wartości i wzorów, które mają w danych warunkach kształtować tożsamość kulturalną narodu, służyć mu jako wzorzec wychowawczy, tworząc ład moralny (Znaniecki 1971). Ład moralny jest dobrem wspólnym, zasobem cywilizacyjnym, z którego czerpią i który przetwarzają kolejne pokolenia. Joseph Conrad (1965, s. 9-10) w swoich Wspomnieniach następująco ujął istotę polskiej tradycji kulturalnej:

„Tak zwany w literackim świecie sclavonism [połączenie słów esclave, niewolnik (fr.) oraz Slav, Słowianin (ang.)] jest absolutnie obcy polskiemu temperamentowi z jego tradycją wolności, jego rycerskim poglądem na moralne wędzidła i przesadnym szacunkiem dla praw jednostki; pominąwszy już ten ważny fakt, że polska umysłowość, zachodnia z natury, kształtowała się na wzorach włoskich oraz francuskich, sympatyzując zawsze, jak świadczy historia, nawet w sprawach religijnych, z najbardziej liberalnymi prądami myśli europejskiej. Bezstronny pogląd na ludzkość we wszystkich jej fazach wspaniałości i nędzy, a przy tym szczególny szacunek dla praw tych, co na tej ziemi pozbawieni są przywilejów, szacunek nie wypływający z pobudek mistycznych, lecz oparty na gruncie prostego koleżeństwa i wzajemnych usług - oto zasadnicze rysy duchowej i moralnej atmosfery w domach, pod których dachem spędziłem niespokojne dzieciństwo; a rysy te wypływają z wewnętrznych głębokich przekonań, niewzruszonych i konsekwentnych, bardzo dalekich od tego humanitaryzmu,

10 Istnieje środowisko, które próbuje do pamięci zbiorowej Polaków wprowadzić wspólnictwo w polityce zagłady ludności żydowskiej. Istniał niewątpliwie margines społeczny, który na różne sposoby w niej uczestniczył. Podzielam pogląd Davida Rieffa (2017, s. 74-75): „Jaspers kładł nacisk na rozróżnienie między winą moralną związaną z tym, co ktoś zrobił, a winą moralną wynikłą $z$ tego, kim jest się oraz na łączenie ich obu. Dziś, gdy mowa o pamięci zbiorowej, mówi nam się, że moralność i etyka wymagają tego połączenia. Oparty na wątpliwej podstawie zbiorowej świadomości, wymóg ten jest też podejrzany intelektualnie. Uwalnia bowiem tych, którzy uznają się za ofiary, od rozróżnienia między rzeczywistymi sprawcami krzywdy a tymi, którzy nic nie zrobili, lub nie zrobili dość, by zapobiec złu. Niezależnie od intencji, jest to zabieg społecznie i politycznie niebezpieczny”. Dalej zaś - cytując Tony'ego Judta — Rieff stwierdza, że taka postawy może prowadzić do „złej moralności i złej historii” (s. 80). 
który wydaje mi się tylko kwestią niepoczytalnych nerwów lub chorobliwego sumienia".

Jest to obraz wyidealizowany, lecz dla realizacji pedagogicznych funkcji mitu narodowego idealizacja jest zaletą, a nie wadą (Kijowski 1984). Conrad zawarł w nim to, co w wyniesionym dziedzictwie kulturalnym uznał za najwartościowsze. Zauważę, że niemal identyczną wizję polskiej tradycji kulturalnej można znaleźć w poświęconych jej rozważaniach i homiliach Karola Wojtyły (2005). Przez wybór i utrwalanie tego, co najbardziej wartościowe, tworzy się cywilizacja.

Mit założycielski jest więc wyabstrahowanym zbiorem przekonań o tym, co $\mathrm{w}$ historii narodu zasługuje na pielęgnację. Te wartości i wzory stanowią kryterium przynależności: ci, którzy są ich świadomi i uznają je, należą do narodu w rozumieniu socjologicznym. Naród jest pojęciem nieostrym. Jego zakres zmienia się $\mathrm{w}$ toku historii; przez długi czas, w Polsce do końca XVIII wieku, obejmował niemal wyłącznie „naród szlachecki”, choć w sensie etnicznym, społecznym i religijnym była to zbiorowość różnorodna. Jego główną instytucją formacyjną był folwark-dwór - jako ośrodek łączący w sobie funkcje prywatne i publiczne oraz gospodarcze i polityczne ${ }^{11}$.

Przyjmuję, że państwo narodowe jest i pozostanie podstawą ładu globalnego, że nie ma społeczeństwa obywatelskiego poza państwem narodowym i systemem wartości, które „wchodzą w skład narodowej kultury” (Szacki 1997, s. 45; por. Shills 1997). W epoce najpełniejszego rozwoju Polski pod względem politycznym i kulturalnym powstała idea narodu obywatelskiego otwartego na różne religie i grup etniczne ${ }^{12}$. Twierdzę na koniec, że choć tradycje te wegetują na marginesie, to nie ma obecnie w Polsce siły politycznej ani wpływowego środowiska kulturalnego, które by je promowały. Może ostatnim takim ośrodkiem było środowisko paryskiej „Kultury”.

\section{DWÓR-FOLWARK W ŻYCIU PUBLICZNYM I KULTURALNYM KRÓLESTWA POLSKIEGO}

Polska weszła $\mathrm{w}$ okres kapitalizmu z opóźnieniem spowodowanym przez wiele różnych czynników. $Z$ tego powodu to właśnie tradycja kultury szlacheckiej stanowi podstawę narodowej tożsamości Polaków. Trafnie pogląd ten ujął Czesław Miłosz (1959, s. 109):

11 „Polski szlachcic nie uważał się za człowieka prywatnego: «ludźmi prywatnymi» byli plebejusze, szlachta natomiast była zbiorowym suwerenem, przynależność do niej uprawniała i zobowiązywała do służenia dobru publicznemu, «rzeczy pospolitej». Ideał «rzeczpospolitej», daleki oczywiście od codziennej praktyki życiowej, zakładał, iż właściwym polem wolności nie jest sfera życia prywatnego, lecz właśnie «rzecz pospolita» [...]" (Walicki 2009, s. 351).

12 Zob. rozróżnienie na narody obywatelskie i etniczne, które zaproponował Christopher Bryant (1997). 
„Zapewne każda cywilizacja otrzymuje na trwałe piętno okresu dla niej kluczowego. Francja wszystko zawdzięcza swemu mieszczaństwu, twórczemu i prężnemu już na parę stuleci przed Rewolucją. W tym samym czasie rozwijała się w Polsce kultura szlachty i dotychczas chłop czy robotnik polski razi Rosjanina, bo jest pod jej wpływem w mnóstwie swoich odruchów, przez co zyskuje od niego złośliwą nazwę "pana»".

Etos szlachecki był tworem feudalnego ustroju stanowego, w którym posiadanie lub brak określonych atrybutów oznaczał wyższość lub niższość położenia społecznego i życiowych szans. Społeczeństwo stanowe składało się z grup społeczne zróżnicowanych pod względem prawnym i funkcjonalnym. Przynależność do nich była w znacznej mierze dziedziczna. Tworzyły one hierarchię przywilejów i zobowiązań, przede wszystkim moralnych, chociaż po części również przyjmujących postać prawną. Na jej szczycie znajdował się stan szlachecki. Urodzenie było koniecznym, ale — przynajmniej w teorii — niewystarczającym warunkiem wysokiego statusu. Obok urodzenia wymagane było spełnienie też innych warunków, wynikających z przynależności do stanu rycerskiego.

Dwór stanowił niezbywalny element organizacji gospodarki feudalnej i ten aspekt historyczny jest kluczem do zrozumienia jego miejsca w systemie współdziałania ekonomicznego oraz konfliktów społecznych nękających tę formację społeczno-gospodarczą. Dwór był centrum życia publicznego, ośrodkiem samorządowym i administracyjnym; był miejscem socjalizacji przyszłych pokoleń w stanowym systemie wartości; pełnił też różnego rodzaju funkcje socjalne na rzecz wsi: obrony i utrzymania porządku, pomocy w przypadku klęsk żywiołowych, rozsądzania sporów itp. Dopiero nowoczesne państwo przyniosło względnie precyzyjne rozgraniczenie sfery publicznej i prywatnej, między innymi oddzielenie prywatnego mieszkania od biura, pojawienie się wyspecjalizowanych służb wykonujących funkcje, które dotychczas pełniła rodzina itd.

„Dwór” jako zjawisko kulturowe związane $z$ wiejską rezydencją i majątkiem ziemskim w wyobraźni Polaków zajmuje ważne miejsce: kojarzy się ze spokojem, bezpieczeństwem, życiem rodzinnym, sielskim krajobrazem wsi — obraz jakże częsty w polskiej literaturze XIX wieku. Dwór był zarazem miejscem kultywowania uczuć patriotycznych: idei społecznej służby, odpowiedzialności za powierzoną sobie zbiorowość - rodzinę, poddanych, a wreszcie odpowiedzialności za los Ojczyzny. Funkcja ta była istotna w okresie, w którym Polska była pozbawiona własnej państwowości: ideę państwowości przechowywano w tradycji przekazywanej z pokolenia na pokolenie między innymi w ziemiańskich dworach.

W społeczeństwie tradycyjnym funkcje rodziny obejmowały obszar, na który dopiero przed mniej więcej stu pięćdziesięciu laty zaczęły wkraczać instytucje państwa. W tym obszarze rola kobiety była szczególnie ważna. W polskiej tradycji szlacheckiej kobieta miała stosunkowo mocną pozycję. Znalazło to wyraz nie tylko w obyczajowości, ale i w prawie cywilnym: prawo posiadania własności i spadkobrania, zarządzania majątkiem pod nieobecność męża, 
występowania przed sądem jako strona (Malinowska 2008). Astolphe de $\mathrm{Cu}$ stine, w listach z Rosji (1995), odnotował w 1839 roku, że gdy w arystokratycznych salonach rosyjskich centralne miejsce zajmowali mężczyźni, salony polskie koncentrowały się wokół kobiet ${ }^{13}$. Podczas zaborów kobiety „[...] wychowywały dzieci w taki sposób, by były zdolne do walki o niepodległość i do życia w wolnym państwie, do wolności myślenia i do dbałości o bezpieczną codzienność" (Pawełczyńska 2010, s. 103). Warto dodać, że przyznanie kobietom pełnych praw wyborczych nastąpiło wraz z odzyskaniem przez Polskę niepodległości w 1918 roku.

W najlepszym okresie demokracji szlacheckiej z dworem łączyły się funkcje samorządowe - stolników, cześników, wojskich, mieczników itd. Te urzędy publiczne były przedmiotem powszechnych aspiracji i nim straciły wszelkie znaczenie, poza symbolicznym, pełniły realne funkcje administracyjne. $\mathrm{Na}$ poziomie powiatów organem samorządu były sejmiki szlacheckie, które wraz z konfederacjami, szczególnie w czasach interregnum, pełniły niezwykle ważne funkcje polityczne umożliwiające zachowanie ciągłości władzy państwowej (Opaliński 2016). Wyrosłe na tym gruncie wartości republikańskie są bodaj najcenniejszą spuścizną pierwszej Rzeczypospolitej. Wzorce takie były względnie trwałe, choć to, w jakim stopniu znajdowały one odbicie w życiu codziennym, zmieniało się zależnie od miejsca i epoki. Podstawą kultury politycznej szlachty było „[...] przekonanie, dla politycznej myśli ówczesnej Europy dość nietypowe, o nadrzędności społeczeństwa i prawa w stosunku do króla i całej władzy państwowej" (Tazbir 1986, s. 75).

Majątki ziemskie w epoce pierwszej Rzeczypospolitej należały do rodzin szlacheckich, które miały też prawny monopol na ich posiadanie. Należy wszak pamiętać, że po pierwsze, stan szlachecki nigdy nie był całkiem zamknięty, bo choć Sejmy od XV wieku niechętnie godność tę nadawały, to przecież zdarzało się to w przypadku szczególnych zasług. Ponadto, jak dowodził Nekanda Trepka w Liber Chamorum, wiele rodzin często skutecznie przenikało do tego stanu droga „osmozy” (Ihnatowicz i in. 2005, s. 148). Jan S. Bystroń (1994, t. 1, s. 195) wspomina o „[...] zjawisku, które w dawnej Polsce przybierało bardzo znaczne rozmiary i niewątpliwie wpłynęło na skład społeczny i na psychikę całej warstwy społecznej. Zjawiskiem tym jest dążenie bardziej ruchliwych, bardziej przedsiębiorczych, często bardziej inteligentnych, czasami tylko bardziej sprytnych żywiołów do uzyskania tytułów szlacheckich, do wejścia w szeregi uprzywilejowanej elity".

Po drugie, wbrew formalnym zakazom jeszcze w XVII wieku zamożne rody mieszczańskie bez przeszkód nabywały folwarki. Po trzecie, w wieku XIX

13 Zbigniew Kuchowicz (1975) krytycznie ocenia pozycję kobiet w dawnej Polsce. Warto jednak zauważyć, że za podstawę oceny przyjmuje on kryteria współczesne, a należałoby raczej zastosować perspektywę porównawczą, czyli spojrzeć na prawa kobiet w innych krajach europejskich, zwłaszcza w zakresie prawa spadkowego oraz podziału majątku w przypadku rozwodu. 
aż do drugiej wojny światowej posiadanie siedziby na wsi było w dobrym tonie wśród zamożnej burżuazji oraz przedstawicieli wolnych zawodów, a pod koniec XIX wieku ziemiaństwo zaczęło utożsamiać się z inteligencją, co świadczy o istotnej zmianie społeczno-kulturowej. W krótkim okresie, od początków wieku XIX do 1939 roku, inteligencja stała się „,zmodernizowanym” następcą stanu szlacheckiego.

Mimo konfliktów, jakie występowały między dworem i wsią do końca, to jest do 1945 roku, dwór pozostawał ważnym ośrodkiem wzorcotwórczym oraz organizatorskim wsi, wpływając na jej kulturę, także kulturę ekonomiczną i rolniczą, oraz kształtowanie się świadomości narodowej (Żaryn 1993) ${ }^{14}$. O jego roli w życiu wsi świadczy energia, z jaką komunistyczne władze niszczyły nie tylko warstwę ziemian, ale i nieodłączny jej atrybut — dwór. Świadczy też o tym pęd, z jakim po 1989 roku rzucili się do przejmowania parków podworskich wraz ze zrujnowanymi na ogół budynkami nie tylko potomkowie dawnych właścicieli, ale częściej nawet osoby przypadkowe. Powstawały w ten sposób formy często pozbawione głębszej treści.

\section{UPADEK USTROJU KONSTYTUCYJNEGO W RZECZYPOSPOLITEJ}

Elementy ustroju konstytucyjnego pojawiły się i rozwijały w Polsce w wiekach XIV-XVI ${ }^{15}$. Był to wynik ukształtowania się pewnej równowagi między monarchami a stanem szlacheckim, której efektem były prawne reguły gry. W XVII wieku ustrój ten znalazł się w stanie pogłębiającego się kryzysu, który w drugiej połowie wieku XVIII doprowadził do rozbioru Rzeczypospolitej przez ościenne potęgi. W opinii, która ma dyskredytować polską tradycję polityczną, do upadku państwa doprowadziła „złota wolność szlachecka”. Tezę tę należy zweryfikować.

W wiekach XV-XVII państwo polskie było monarchią mieszaną, jej organami były: monarcha, element arystokratyczny reprezentowany przez senat oraz element demokratyczny reprezentowany przez izbę poselską. Podstawowy konflikt w ramach klasy politycznej dotyczył relacji między możnowładcami a średnią szlachtą. Miał on wymiar ustrojowy: pierwsi pełnili najważniejsze urzędy państwowe i zasiadali w senacie; drudzy - dominowali w sejmie. Instytucja monarchy odgrywała w pewnym stopniu rolę języczka u wagi. Na dynamikę konfliktu wpływał związek Królestwa Polskiego z Wielkim Księstwem Litew-

\footnotetext{
14 Paweł Soloch, komentując ten tekst, zwrócił mi uwagę na rolę w rozbudzaniu i utrzymywaniu świadomości narodowej księży, wykształconych w diecezjalnych seminariach duchownych. Podobną rolę zresztą odegrało duchowieństwo na całym obszarze Europy Środkowo-Wschodniej.

15 Juliusz Bardach (1984, s. 55-58), wraz z wieloma innymi historykami piszącymi o ustroju Rzeczypospolitej, za początek polskiego konstytucjonalizmu uznaje uchwalenie w 1505 roku Nihil Novi. Nie zajmuje mnie tu kwestia, czy w Polsce istniała tradycja liberalna (Szacki 1994, s. 56-62). Pojęcie „liberalizm” uległo głębokiej ewolucji i obecnie, w postaci „poprawności politycznej”, stanowi wręcz zaprzeczenie wolności jednostki.
} 
skim. Początkowo miał on charakter unii personalnej łączącej dwa oddzielne organizmy polityczne. Dopiero podpisanie unii lubelskiej w 1569 roku nadało mu postać zinstytucjonalizowaną. W obu przypadkach, najpierw o sojuszu, a później związku tych państw, zadecydowało zagrożenie zewnętrzne, początkowo ze strony Zakonu Krzyżackiego, później - Moskwy, Turcji i Szwecji. Utworzona w ten sposób Rzeczpospolita była państwem wielu narodów i religii ${ }^{16}$. Na pilną potrzebę połączenia tych organizmów państwowych formalną unią wpłynął brak naturalnej sukcesji po Zygmuncie Auguście. Podkreślenia wymaga, że połączenie Polski i Litwy nastąpiło w drodze pokojowej, na gruncie wzajemnego poszanowania praw obu partnerów.

$\mathrm{Z}$ uwagi na interes bezpieczeństwa unia lubelska pozostawała $\mathrm{w}$ żywotnym interesie obu państw: tylko wspólnie mogli stawić czoło zewnętrznym zagrożeniom. $\mathrm{Z}$ tego punktu widzenia był to akt mądrości politycznej. Jednak w dalszej perspektywie sposób i okoliczności jej zawarcia przyczyniły się do eskalacji patologii ustrojowych, a w konsekwencji do upadku państwa. Przede wszystkim przyczyniły się do ogromnego wzrostu nierówności majątkowych wśród klasy politycznej, prowadząc do oligarchizacji rządów, co wpłynęło fatalnie na sprawność państwa. Ponadto błędem o tragicznych dla Rzeczypospolitej skutkach było włączenie Ukrainy do Korony.

Co do pierwszej kwestii, XVI wiek był w Polsce epoką szczególnej aktywności politycznej szlachty na rzecz reformy państwa - ruchu egzekucyjnego. Stanisław Tarnowski (2000, s. 100) pisał o tej epoce: „Nowej konstytucji, nowych praw fundamentalnych potrzebowała Polska i czuła, że ich potrzebuje. $Z$ tego popędu mogło było zrobić się coś wielkiego. Pozostał daremnym, a w skutkach szkodliwym [...]". Królowie, z wyjątkiem Zygmunta Augusta w ostatniej dekadzie jego panowania, zamiast wykorzystać sojusz ze szlachtą do przeprowadzenia reformy państwa - nadać zinstytucjonalizowaną formę sejmowi, uzdrowić finanse, zlikwidować inkompatibilia, zreorganizować wojsko i sądownictwo, uregulować sprawę sukcesji - konsekwentnie trzymali stronę niezainteresowanej reformą magnaterii. Monarchia konstytucyjna była w zasięgu ręki, ale ten historyczny moment pozostał niewykorzystany (Butterwick 2010, s. 36).

Od końca XV wieku główną osią podziału politycznego był konflikt między średnią szlachtą i możnowładztwem, który przekładał się bezpośrednio na strukturę państwa: szlachta dominowała w sejmie, możnowładcy — w senacie. W pierwszym okresie przewagę uzyskał sejm, który miał być, formalnie rzecz biorąc, jedynym źródłem stanowienia praw. Problem tkwił w ich egzekucji. Cóż

16 „Naród polski i litewski w nazwie państwa oznaczał faktycznie naród państwowy, zwany do dziś często politycznym; oba obejmowały szlachtę różnojęzyczną, wieloetniczną, wieloreligijną. Szlachta ruska, białoruska i ukraińska, jak je obecnie określamy, stanowiła wraz z polską i litewską trzon ogromnej na owe czasy społeczności, o bardzo różnej kondycji ekonomiczno-społecznej, ale cieszącej się szerokimi uprawnieniami gwarantującymi każdemu daleko idącą wolność i poczucie bezpieczeństwa" (Kłoczowski 2002, s. 135). 
$z$ tego, że sejm uchwalił zakaz łączenia urzędów (incompatibiles), by ograniczyć konflikt interesów, skoro królowie tej zasady nie respektowali? Cóż z tego, że szlachta domagała się zwrotu królowi zawłaszczonych przez magnaterię dóbr koronnych, skoro sami królowie nie byli skłonni kruszyć o to kopii. Szlachta w swych reformatorskich dążeniach szukała współpracy z monarchią. "Jednak owa taktyczna próba ze strony szlachty połączenia sił z królem przeciwko majątkowej i politycznej potędze magnatów nie powiodła się, gdyż Jagiellonowie nie dążyli do stworzenia królewskiego stronnictwa poprzez zjednanie sobie zwykłej szlachty" (Bues 2010, s. 90) ${ }^{17}$. Królowie z dynastii Wazów przyjęli w polityce wewnętrznej jeszcze bardziej sprzyjający magnaterii kurs ${ }^{18}$. Problem polegał na tym, że król i senat blokowali reformatorskie zapędy szlachty, a $z$ kolei sejm, w proteście przeciw polityce króla blokował, z cichym poparciem senatu, próby podniesienia podatków na cele obronne (Seredyka 1981, s. 116).

Połączenie w jeden organizm polityczny Królestwa i Wielkiego Księstwa Litewskiego umocniło przewagę magnaterii (Wyczański 1965, s. 93; Kiaupienė 2010, s. 118). Od tego momentu magnaci kresowi stają się główną siłą polityczną Rzeczypospolitej (Dzięgielewski 1993, s. 78) ${ }^{19}$. Skutkiem tego sejm traci znaczenie na rzecz senatu, który wbrew prawu, z poparciem królów, w coraz szerszym zakresie zaczyna pełnić funkcje ustawodawcze. Jednocześnie sejm tracił w XVII wieku znaczenie na rzecz sejmików powiatowych, podczas których magnaci, z pomocą rzeszy klientów oraz instytucji liberum veto, mogli skuteczniej przeprowadzić swoją wolę ${ }^{20}$.

Po drugie, źródłem dramatycznych trudności dla Rzeczypospolitej stało się włączenie do Korony ziem ukrainnych, które uprzednio były częścią Wielkiego Księstwa Litewskiego. Jak pisał Jerzy Kłoczowski (2002, s. 148): „To, że nie udało się przekształcenie unii lubelskiej 1569 roku w unię trzech narodów, stanowiło jej wielką klęskę zarówno Polaków i Ukraińców, jak i Litwinów i Bia-

17 Jest to sytuacja nietypowa, bo należałoby się raczej spodziewać po władcach podjęcia próby stworzenia takiej partii (Weber 2002, s. 210). W przypadku Jagiellonów można to wyjaśnić tym, że ruch egzekucyjny obejmował głównie Polskę, to jest tę część Rzeczypospolitej, w której sukcesja była uwarunkowana przez elekcję, w odróżnieniu od Wielkiego Księstwa Litewskiego, gdzie władza była dziedziczna. Możliwe też, że przyczyną była organizacja i siła szlachty, co czyniło taki alians zbyt ryzykownym.

18 Ten rozwój wydarzeń potwierdza wniosek, który Nancy Bermeo (2003) wysnuła z badań porównawczych nad przypadkami upadku demokracji w XX wieku. Jej zdaniem prowadziły do tego kalkulacje i strategie elit, a nie zachowania i postawy zwykłych obywateli.

${ }^{19} \mathrm{Na}$ brak symetrii w ponoszeniu ciężarów obrony przez Litwę i Polskę oraz wciąganie Polski w zbędne konflikty powodowane samodzielną polityką zagraniczną litewskich magnatów zwrócił uwagę Andrzej Wyczański (1965, s. 93).

20 Podobne diagnozy przełomu ustrojowego można znaleźć u historyków współczesnych. Jan Dzięgielewski (1993, s. 93) pisze: „Przestało [...] realnie funkcjonować systemowe (instytucjonalne zabezpieczenie strzegące uprawnień urzędów państwowych, powodując, że problem utrzymania bądź naruszenia ich kompetencji stał się całkowicie zależny od roztropności i odpowiedzialności uczestników życia publicznego oraz aktualnego rozkładu sił”. Przykład trudności w tworzeniu spójnej polityki obronnej Rzeczpospolitej przytacza też Jan Seredyka (1981, s. 18). 
łorusinów". Błąd ten miała skorygować unia w Hadziaczu (1659), ale przyszła o blisko sto lat za późno.

Zawarcie unii rozpoczęło na wielką skalę kolonizację Ukrainy przez zasiedlanie „dzikich pół” zbiegłymi pańszczyźnianymi chłopami z Polski, szukającą nowych szans życiowych drobną szlachtą lub zwykłymi awanturnikami. Uwikłało to Koronę w spór między żądającymi zrównania ze szlachtą wolnymi wojownikami - kozakami - a magnatami pragnącymi przekształcić ich w pańszczyźnianych chłopów. Polityczna i społeczna dominacja wielkich latyfundiów kresowych powodowała konflikty, których w innych warunkach Rzeczpospolita mogła uniknąć. Opinia Janusza Tazbira (1997, s. 8) wiele tu wyjaśnia:

„[...] wbrew utartym schematom, powstania kozackie były nie tyle walką uciskanych ruskich chłopów z polską magnaterią, co starciem zrutenizowanych polskich włościan ze spolonizowaną ruską szlachtą. [...] Trudno [...] nie przyznać, że wszystkie bunty kozackie, z powstaniem Chmielnickiego na czele, zawierały w sobie tę samą, również obiektywnie rzecz biorąc, chęć rewizji postanowień unii lubelskiej".

Polonizacja szlachty dawnego Wielkiego Księstwa Litewskiego i Ukrainy spowodowała, że na kresach wschodnich dawnej Rzeczypospolitej polski, katolicki dwór znalazł się w obcym otoczeniu: na Ukrainie i Białorusi wobec spragnionego ziemi, prawosławnego chłopstwa; na Litwie - w obliczu rosnącej świadomości odrębności narodowej Litwinów. Małe miasteczka zaś zdominowała ludność żydowska, która zmonopolizowała handel. $Z$ wyjątkiem tego ostatniego, stworzyło to warunki pod pewnymi względami podobne do tych, jakie istniały w Irlandii pod panowaniem angielskim. Procesy modernizacyjne musiały prowadzić do zaostrzenia się konfliktów. Czy Polacy mogli inaczej prowadzić na tych terenach swoje sprawy? Jak pod koniec XIX wieku pisał Tadeusz Bobrowski (1979, t. 2, s. 444), wielki realista i znawca przedmiotu:

Na ziemiach, „[...] w których jako element historycznie cywilizacyjny (było nas mniej więcej 400000 na 7000000 ludności Małorosyjskiej) mogliśmy zachować nawet na pewien czas stanowisko przewodnie, lecz bynajmniej nie imponujące - i tylko pod warunkiem przestrzegania najściślejszego równouprawnienia nie tylko cywilnego, ale i społecznego i obyczajowego w stosunkach z ludnością miejscową i oddawania jej posług, które w społeczeństwach prawidłowo i zdrowo uorganizowanych, a świadomych zadań i celów społecznego życia - więcej cywilizowane, więcej doświadczone i bogatsze warstwy zwykłe i winne mniej szczęśliwie uposażonym oddawać!".

Nie było to łatwe i nic nie wskazuje, by środowisko, przed którym Tadeusz Bobrowski zadanie takie postawił, przyjęło je z powagą, na jaką zasługiwało.

Rozkładowi Rzeczypospolitej towarzyszyły rosnące zagrożenia wewnętrzne i zewnętrzne oraz regres gospodarczy. Łącznie czynniki te doprowadziły do 
upadku państwa ${ }^{21}$. Na przełomie wieków XVI i XVII na niekorzyść Rzeczpospolitej zmieniły się warunki wymiany gospodarczej z zachodem Europy (terms of trade), a wynikła z odkryć geograficznych zmiana głównych szlaków handlowych pogorszyła jej pozycję jako obszaru tranzytowego. Do tego doszła błędna polityka monetarna władców (Sadowski 1964). Sytuacja gospodarcza osłabiła politycznie szlachtę koronną na rzecz kresowej magnaterii.

Koniec XVI wieku jest początkiem końca ustroju republikańskiego w Polsce. Przełom XVII i XVIII wieku to okres jego postępującego rozkładu, lecz pamięć o wysokiej kulturze politycznej, która cechowała Rzeczpospolitą czasu jej potęgi, przetrwała, znajdując wyraz w reformach Sejmu Wielkiego i Konstytucji 3 Maja, a także później. O tym dorobku tak pisał Jerzy Kłoczowski (2002, s. 173):

„[...] doświadczenia kilkuset lat wzbogacone o dorobek pokolenia Wielkiego Sejmu i powstania Kościuszki pozostawiły następnym pokoleniom mieszkańców całego obszaru Rzeczypospolitej dziedzictwo ogromnej wagi. Jego nosicielami byli w pierwszym rzędzie ludzie narodu politycznego Rzeczypospolitej określający się najogólniej jako Polacy w sensie polityczno-obywatelskim. Tak pojętymi Polakami byli więc w ówczesnych i długotrwających pojęciach także Litwini czy Rusini, czasem Żydzi, Niemcy, Ormianie; ludzie różnych narodowości, języków, religii. Tak pojmowała polskość i Polskę między innymi Wielka Emigracja po 1830/1831 roku w swych obu nurtach, demokratycznym i konserwatywnym; Emigracja, której bogaty i wielostronny dorobek wywarł ogromny wpływ na następne pokolenia Polaków".

\section{OD ETOSU SZLACHECKIEGO DO ETOSU INTELIGENCJI}

Podstawą etosu szlacheckiego była tradycja rycerska. Jej treść zmieniała się $z$ upływem czasu i warunków. Jej istotą był honor i to, co pojęcie to zawierało: odwaga, lojalność, hojność w stosunku do osób zależnych, dbałość o powierzonych sobie ludzi, wielkoduszność, o sprawności wojennej nie wspominając, wreszcie kultura obycia (Zakrzewski 2004) ${ }^{22}$. Dołączyły do tego później dworskie maniery i wymóg wykształcenia ogólnego, przede wszystkim klasycznego: historia, greka i łacina wraz ze znajomością starożytnej filozofii i literatury. W miarę rozwoju sztuki wojennej znaczenia nabrała też wiedza techniczna.

\footnotetext{
${ }^{21} \mathrm{~W}$ pracy poświęconej Rzeczypospolitej Helmuth von Moltke, twórca pruskiego sztabu generalnego i architekt pruskich zwycięstw nad Danią, Austrią i Francją, zwrócił uwagę na rolę moralności publicznej szlachty w osiągnięciu przez Rzeczpospolitą międzynarodowego znaczenia, a zarazem na niemożność zreformowania państwa. Zmiana w układzie sił politycznych doprowadziła do tego, że: „dawne prawa trwały dalej, lecz obyczaje były inne, a ponieważ żadne prawo nie może istnieć w sprzeczności z obyczajami, to i tutaj pozostały tylko formy, pod które podstawiono nowe znaczenie; a było to nieszczęściem, przeciw któremu ustrój państwa nie znał środka, ponieważ podkopywało ono sam ustrój" (Moltke (1996 [1831], s. 14).

${ }^{22}$ Leszek Zakrzewski (2004), na podstawie artykułu Małgorzaty Melchior (1983), wskazał na związek etosu Szarych Szeregów z tradycją rycerską.
} 
Szkoła Rycerska w drugiej połowie XVIII wieku uczyniła z niej jeden z priorytetów w nauczaniu. Obok uniwersytetów: Jagiellońskiego, Wileńskiego i Lwowskiego, powstały zakłady oświatowe i naukowe tej miary, co Liceum Krzemienieckie lub Szkoła Główna w Warszawie.

Epoka rycerstwa minęła, ale część jego spuścizny pozostała, zdaniem niektórych autorów, aktualna. Maria Ossowska (1986, s. 122) wiązała z nią wzór osobowy gentelmana ${ }^{23}$. Etos rycerski, uważała, winien regulować wszelkie sytuacje walki czy rywalizacji, które w życiu społecznym są nie do uniknięcia:

„Walka winna być prowadzona według starych tradycji rycerskich, z poszanowaniem przeciwnika i [...] z unikaniem wszelkiej krzywdy niekoniecznej dla przeprowadzenia swych celów. Do tej tradycji rycerskiej warto szczególnie nawiązać dzisiaj, w okresie, gdy ludzie nie przebierają w środkach, by przeciwnika pogrążyć; gdy śmierć wroga im nie wystarcza; gdy muszą jeszcze ponadto jego obraz dla potomności splugawić" (Ossowska 1986, s. 30).

W eseju o wzorze obywatela-demokraty zalecała:

„Szkicując obraz człowieka, jakiego mamy hodować, nie można pominąć jeszcze jednego, bardzo doniosłego punktu, a mianowicie postawy, jaką powinniśmy zajmować wobec przeciwnika w walce, walka bowiem jest sytuacją powszednią. Mamy z nią do czynienia nie tylko na wojnie. Jest nią rozgrywka parlamentarna, wszelka polemika, jest nią partia szachów czy partia tenisa" (Ossowska 1992, s. 29-30).

Poczucie godności, umiłowanie wolności i identyfikacja ze wspólnotą - te wartości etosu rycerskiego $\mathrm{w}$ jakimś stopniu przetrwały prawie do naszych czasów. Winston Churchill (1960, s. 312) w dziele o drugiej wojnie światowej pisał z właściwą sobie emfazą:

„[...] jeśli nie będziesz walczyć o słuszną sprawę, kiedy możesz łatwo wygrać bez rozlewu krwi; jeśli zaniechasz walki, gdy zwycięstwo jest pewne i niezbyt kosztowne, może przyjść chwila, kiedy będziesz musiał walczyć, mając wszystko przeciw sobie i tylko niewielką szansę przetrwania. Może być jeszcze gorzej: możesz być zmuszony walczyć, gdy nie ma nadziei na zwycięstwo, bo lepsza śmierć niż życie w niewoli".

Warto o tym pamiętać, gdy oceniamy polskie powstania, aż po powstanie w getcie lub powstanie warszawskie ${ }^{24}$. Pamiętajmy też, że powstanie warszaw-

23 Cytowany przez Ossowską (1986, s. 151-152) Bertrand Russell (Human Society in Ethics and Politics, London 1954, 42-43) pisał: „Gdy uwolni się koncepcję honoru od arystokratycznej buty i skłonności do gwałtu, zostanie w niej coś, co pomaga człowiekowi zachować osobistą prawość i szerzyć wzajemne zaufanie w stosunkach społecznych. Nie chciałbym, aby ten legat wieku rycerstwa został dla świata całkowicie zaprzepaszczony".

${ }^{24}$ Henryk Wereszczycki (1987, s. 22), omawiając spór między Aleksandrem Wielopolskim a Andrzejem Zamoyskim, pisał: ,jeśli traktować postawę Andrzeja Zamoyskiego jako irracjonalną, bo kierującą się uczuciem, to jednak nigdy nie można wykluczyć, że są sytuacje polityczno-narodowe, w których odruch uczucia patriotycznego może być obiektywnie mądrzejszy niż zimne wyrachowanie". 
skie było ostatnim akordem unikatowego $\mathrm{w}$ historii drugiej wojny światowej wydarzenia - Polskiego Państwa Podziemnego, z wojskiem, aparatem sądowym, administracją, systemem edukacji na wszystkich poziomach. Jeżeli szuka się dowodu na zdolność społeczeństwa do samoorganizacji, to trudno o bardziej przekonujący. Sądzę, że niezależnie od tego, jaką decyzję podjęłoby dowództwo AK, końcowi Polskiego Państwa Podziemnego musiałyby towarzyszyć wydarzenia tragiczne.

\section{ZMIERZCH SPOŁECZEŃSTWA STANOWEGO: OD SZLACHTY DO INTELIGENCJI}

W hierarchii stanowej szlachta zajmowała miejsce najwyższe, dlatego elementy jej stylu życia — etosu — przejmowały środowiska aspirujące do awansu społecznego ${ }^{25}$. Nie była to w Europie sytuacja wyjątkowa. Również biurokracja ukonstytuowała się w XIX wieku jako grupa stanowa (Weber 2002, s. 696); średniowieczne włoskie mieszczaństwo też przejmowało wzory z etosu rycerskiego; nie zapominając o wojsku, zwłaszcza w Europie, którego podkultura dotychczas nawiązuje wprost do tych tradycji.

Zmierzch społeczeństwa stanowego następował, z większym lub mniejszym opóźnieniem, w sposób podobny w całej Europie: stany „niższe”, zachowując elementy własnych podkultur, przejmowały symbolikę utożsamianą z przynależnością do stanów „wyższych”. W Polsce objęło to warstwę mieszczańską, często pochodzenia niemieckiego lub żydowskiego ${ }^{26}$. W przypadku mieszczaństwa pochodzenia niemieckiego procesy polonizacji następowały szybko - już w drugim, a czasem w pierwszym pokoleniu. Jednocześnie wiele rodzin ziemiańskich traciło majątki na skutek złego gospodarowania lub popowstaniowych represji i zasilało ludność miast. W miarę upowszechniania się w warstwie ziemiańskiej wzorca wykształcenia na poziomie co najmniej średnim coraz więcej jej potomków szukało zatrudnienia w miastach. Z czasem też rósł, spowodowany rozwojem przemysłu, napływ do miast ludności chłopskiej. W ten sposób powstawała w Polsce specyficzna warstwa inteligencji, pod pewnymi względami nawiązująca do tradycji szlacheckich i po części złożona $z$ potomków rodzin szlacheckich, ale jej skład społeczny był z pewnością znacznie bardziej różnorodny, niż sugerował w swoim eseju Chałasiński (zob. Ihnatowicz i in. 2005, s. 526).

Stan inteligencki był kategorią pojemną, pośredniczącą $\mathrm{w}$ relacjach między klasami społecznymi, grupami etnicznymi, środowiskami zawodowymi (Cze-

25 Temat czynników wpływających na przejmowanie wzorów i intensywność tego procesu szeroko rozważała Maria Ossowska (1986).

26 „Do końca XIX wieku poza kresami wschodnimi cała elita społeczeństwa żydowskiego stała się polska. Dopiero masowe przesiedlenia Żydów z głębi Rosji na ziemie polskie w latach 1880-tych zahamowały ten proces, a ci Żydzi zwani litwakami pozostali poza zasięgiem kultury polskiej” (Wereszczycki 1987, s. 33-34). 
pulis-Rustenis 1973, 1976; Kurczewska 2008). Jego członkowie uważali się za elitę i za taką byli uznawani. Ta elita miała być służebna wobec narodu. To zobowiązanie moralne dobitnie wyrażała twórczość pozytywistów, a później Stefana Żeromskiego. W epoce rozbiorów, wobec braku własnej państwowości, taka konstrukcja tożsamości grupowej miała daleko idące konsekwencje. Utrwalała bowiem poczucie odpowiedzialności za przechowanie narodowych tradycji i niepodległościowych aspiracji.

W XIX wieku, według Anny Pawełczyńskiej (2004, s. 126-128): „Inteligenci [...] odebrali ziemiaństwu prymat jako warstwie wzorcotwórczej”. Integralną częścią jej etosu była dbałość o kulturę wewnętrzną, obejmująca też wrażliwość na sytuację konkretnych ludzi, honor i poczucie własnej godności. „Normom regulującym postępowanie związane ze sferą moralności towarzyszył bardzo bogaty i zróżnicowany zespół norm obyczajowych, określających kulturę życia codziennego i przekazywanych przekazem rodzinnym z pokolenia na pokolenie". Obejmowały one myślenie i działanie zgodne $z$ obywatelskim obowiązkiem, poczuciem odpowiedzialności za losy kraju, bezinteresowną troską o dobro narodu. Etos inteligencki „,...] stanowił tak silne zagrożenie dla kolejnych okupantów, że mając tego świadomość, dążyli do całkowitej zagłady tej warstwy". W wiekach XIX i XX mamy więc inteligencję jako przejściowy stan społeczny, obejmujący ziemiaństwo, mieszczaństwo, w tym ludzi trudniących się twórczością umysłową i urzędników.

W wieku XIX szlachta i arystokracja stały się przeżytkiem, tracąc kolejno swe przywileje, choć pobudzając czasem ludową wyobraźnię. Prowadzone często na sposób tradycyjny majątki nie wytrzymywały konkurencji na rynku. Zdarzali się często posesjonaci-rentierzy, traktujący majątki jako źródło środków na wystawną konsumpcję, co niszczyło skłonność do oszczędzania i inwestycji. Postawa taka była często piętnowana w literaturze pięknej XIX i początku $\mathrm{XX}$ wieku oraz we wspomnieniach $\mathrm{z}$ tego okresu ${ }^{27}$. Zasługuje jednak na przypomnienie, że już rząd Królestwa Kongresowego skutecznie realizował politykę rozwoju gospodarki, związaną z osobą Xawerego Druckiego-Lubeckiego (Smolka 1907). Próby te zniweczył wybuch powstania listopadowego. Również schyłek XIX wieku, aż po pierwszą wojnę światową był okresem intensywnego rozwoju gospodarczego ziem polskich pod zaborem rosyjskim, a także pruskim.

Etos szlachecko-inteligencki, szczególnie w zaborze rosyjskim, w drugiej połowie XIX wieku uległ znaczącej ewolucji. Klęska powstania styczniowego uświadomiła elitom wartość „pracy organicznej”, skupionej na edukacji narodu, rozwoju gospodarki, umacnianiu poczucia tożsamości narodowej wśród ludności wiejskiej. Takie postawy pojawiały się wcześniej w zaborze pruskim.

${ }^{27}$ Co do literatury pięknej, można wspomnieć o licznych utworach Elizy Orzeszkowej, Józefa Kraszewskiego, Bolesława Prusa i wielu innych. Przykładem literatury pamiętnikarskiej są wspomnienia Tadeusza Bobrowskiego (1978), Wacława Lednickiego (1963), czy Hipolita Korwin-Milewskiego (1930). 
Edukacja i działalność gospodarcza stały się częścią walki o niepodległość. Towarzyszyła temu świadomość, że wysiłek zbrojny nie jest czymś, co należy do przeszłości. W praktyce tradycja romantyczna pozostawała $\mathrm{W}$ symbiotycznym związku z ideologią pozytywizmu. Młodzież wychowywano do służby narodowi praca, a gdy zajdzie konieczność - zbrojnie. Była to tradycja par excellence obywatelska, która kazała brać pod uwagę obowiązek wobec Ojczyzny — aż po poświęcenie życia w jej obronie.

\section{ZAKOŃCZENIE}

Ważnym tematem debat publicznych jest wpływ globalizacji na funkcjonowanie państwa narodowego. Skrajne stanowisko głosi, że wraz z postępem globalizacji państwo narodowe straci rację bytu i zniknie. Jest to epigońska wersja marksizmu. Przeczy mu nie tylko ogólna teoria systemów mówiąca, że wraz ze wzrostem złożoności otoczenia rośnie liczba szczebli hierarchii regulacji (Pattee 1973). Przeczy mu też historia globalizacji: (1) jej podstawą są porozumienia między rządami państw narodowych; (2) a rolę wiodącą odegrały państwa pełniące w danej epoce rolę hegemona. Globalizacja wpływa na funkcjonowanie państw narodowych przez wymuszanie co najmniej cząstkowej adaptacji do wymogów globalnego układu polityczno-gospodarczego. Państwo narodowe jest względnie samodzielnym szczeblem wewnętrznej agregacji interesów i koordynacji współdziałania.

Pośrednie, choć nie całkiem konsekwentne, stanowisko zajęła Mirosława Marody (2014, s. 130). Według niej, „państwo jako forma organizacji politycznej dobrze się miewa”. Niemniej jednak „[... ] jako specyficzna instytucja wyrastająca z nowoczesnej formy uspołecznienia ludzkich działań [...] ulega stopniowo rozpadowi. Tym samym, podkopany zostaje również sam fundament «obywatelskości» jako podstawy podporządkowujący interesy jednostek ogólnym zasadom działań społecznych [...]”. W efekcie musi nastąpić przeorientowanie działań na inne niż narodowe centra integracji. Tezie o dobrej kondycji państwa zaprzecza dalszy ciąg wywodu autorki, o „uleganiu rozpadowi” i "podkopaniu fundamentu" w postaci instytucji obywatelstwa. Jeżeli bowiem państwa narodowe są podstawą globalizacji, to ich kryzys zagraża procesom globalizacyjnym, a więc i trwałości cywilizacji. Zresztą Marody (2014, s. 304), nawiązując do koncepcji Lestera Thurowa, dostrzega, że starożytny Rzym upadł właśnie z powodu rozkładu etosu kulturalnego, który wcześniej napędzał jego rozwój. O czym pisał już Monteskiusz i wielu innych.

Nie zmienia to faktu, że jako twór osiemnastowiecznych koncepcji ustrojowych państwo przeżywa kryzys. Na poziomie globalnym zaś agregacja interesów narodowych i koordynacja współdziałania między państwami odbywa się z trudnościami, u których podstaw leży konieczność współistnienia państw zbudowanych na zasadach liberalno-konstytucyjnych, opartych na rządach prawa, które stworzyły współczesną cywilizację, z potężnymi państwami, które 
wyrosły z rozkładu ustrojów totalitarnych. Konstrukcja ustrojowa tych ostatnich jest sprzeczna z logiką systemu globalnego, którego stabilność wymaga przestrzegania reguł prawa międzynarodowego. Obok kryzysu instytucji liberalno-demokratycznych posttotalitarna kontestacja jest więc drugim najważniejszym politycznym zagrożeniem dla trwałości współczesnego ładu światowego. Należy jednak pamiętać, że innego ładu, który byłby do przyjęcia na gruncie zachodniego systemu wartości, na horyzoncie nie ma.

Skoro państwo narodowe, a zatem poziom integracji społecznej i polityczno-gospodarczej na tym szczeblu, nie tracą racji bytu, to - co do zasady — nie tracą racji istnienia związane $z$ nim instytucje, $w$ tym instytucja obywatela i jej kulturowa podstawa - etos narodowy. Bez niego obywatelstwo pozbawione jest niezbędnych podstaw moralnych, przestaje istnieć jako instytucja w sensie socjologicznym. Na samych ideach, jak i na samych interesach partykularnych nie zdołał powstać żaden ład społeczny. Tożsamość historyczna jest potężnym i niezastąpionym źródłem obywatelskiej motywacji.

Jak pisałem, etos narodowy jest efektem zbiorowego wyboru wartości i wzorów, które w danych warunkach kształtują tożsamość kulturalną narodu, integrują wspólnotę i służą jej za wzorzec wychowawczy (Kijowski 1984; Shills 1997). Z tego punktu widzenia, walka $z$ patriotyzmem i narodową tożsamością jest, by zacytować Conrada, „humanitaryzmem, który wydaje się kwestią niepoczytalnych nerwów lub chorobliwego sumienia". Problem sprowadza się do wyboru z tradycji narodowej tych wzorów i wartości, które należy uznać za współcześnie najcenniejsze dla tożsamości narodowej Polaków. Istnieje w niej wiele elementów, które zasługują na przypomnienie i pielęgnowanie. Obecny w niej był szacunek dla rządów prawa, zdolność budowania porozumienia i współpracy bez uciekania się do siły, samoorganizacja społeczna, poczucie odpowiedzialności za losy wspólnoty oraz — wbrew niektórym opiniom — otwartość na obcych.

W historii ostatnich czterech dekad w Polsce zaskakuje wpierw erupcja obywatelskiej aktywności społeczeństwa i manifestacja jego potencjału samoorganizacyjnego w latach 1980-1991. Świadczyła ona o trwałości tradycji szlachecko-inteligenckiej. Latem 1980 roku Polacy byli w stanie w ciągu paru tygodni wyłonić zespół utalentowanych przywódców politycznych i powołać do życia organizację liczącą niemal dziesięć milionów członków. Osiem lat później — na bazie ruchu solidarnościowego oraz organizacji wspieranych przez Kościół powstał, obejmując cały kraj, ruch komitetów obywatelskich, który zadecydował o zwycięstwie antykomunistycznej opozycji w wyborach 4 czerwca 1989 r. Badania nad tym ruchem pokazały zaskakująco wysoki, biorąc pod uwagę komunistyczną przeszłość społeczeństwa, poziom kultury osobistej i zdolności organizatorskich tworzących go ludzi (Słodkowska 2014). Po zwycięstwie Solidarności w czerwcowych wyborach komitety obywatelskie odegrały jeszcze kluczową rolę w wyborach samorządowych w 1990 roku, pojawiły się w „wojnie na górze", w której część obozu solidarnościowego wystąpiła przeciwko Lechowi 
Wałęsie i jego zwolennikom, a następnie uległy stopniowej dezintegracji. Komitety obywatelskie były ostatnią wielką manifestacją tradycji inteligenckiej, choć elementy tego etosu można było jeszcze dostrzec $\mathrm{w}$ działalności rządu Jerzego Buzka. Owocem ich działalności, wspartej przez niewielkie środowisko działaczy politycznych i naukowców, były obie reformy samorządowe - z 1990 i 1998 roku (Regulski 2001).

Odpowiedź na pytanie o źródła polityki demobilizacji społeczeństwa obywatelskiego wykracza poza ramy tych rozważań. Nasuwa się jednak intuicja, która zasługuje na zasygnalizowanie. Ruch komitetów obywatelskich był podporządkowany idei wspólnego dobra jako sprawy łączącej jego uczestników, a zatem miał charakter programowo ponadpartyjny. Kierownictwo ruchu solidarnościowego i Komitet Obywatelski przy Lechu Wałęsie bardzo wcześnie zdominowała walka o władzę i przywileje, usuwając na bok kwestię strategiczną, która mogłaby zmobilizować i ukierunkować energię twórczą całego społeczeństwa: budowę dobrego państwa. Słynna „wojna na górze” nie była dziełem przypadku jej korzenie sięgają co najmniej połowy lat osiemdziesiątych. A jej efektem była ponowna w historii „utrata momentu konstytucyjnego”. Z tego wynikła słabość instytucji państwa oraz oligarchizacja rządów (Kamiński 2014). Utrwaliło tę tendencję przyjęcie $\mathrm{w}$ wyborach do sejmu ordynacji proporcjonalnej. Partie polityczne stały się korporacjami zawodowymi „łowców posad”, co sprowadza państwo z jego instytucjami do roli zawłaszczanego przez zwycięzców łupu, a nie instrumentu realizacji wspólnego dobra.

Wypieraniu ducha obywatelskiego towarzyszyła propaganda mediów kontrolowanych przez część środowiska byłej Solidarności. Na przełomie lat 1989 i 1990, niemal z dnia na dzień, zmieniły one swą narrację o społeczeństwie polskim: dotychczas „dojrzałe”, „racjonalne” i „odpowiedzialne” teraz stało się kolebką „obskurantyzmu”, „ignorancji”, „antysemityzmu” i „szowinizmu” 28. Ta uprawiana przez „internacjonalistów” „pedagogika wstydu”, jak określają ją jej krytycy, jest również opcją na rzecz określonego etosu, a raczej antyetosu narodowego ${ }^{29}$. Pod tą pokrywką „humanistycznych wartości” kryje się nihilizm.

${ }^{28}$ Trafny opis tej ewolucji można znaleźć w książce Zdzisława Krasnodębskiego (2003), chociaż $\mathrm{w}$ wielu innych kwestiach nie podzielam jego stanowiska.

${ }^{29} \mathrm{~W}$ owej „pedagogice wstydu” silnie eksponowana jest sprawa antysemityzmu i współwiny Polaków za Holokaust. Stosunki polsko-żydowskie wymagają badania, ale nie w aspekcie Holokaustu, który nie w Polsce był wymyślony, ale w aspekcie koegzystencji w określonych warunkach historycznych (zabory, modernizacja, wojny i gospodarcze kryzysy) dwu — różnych pod względem religii, języka i obyczaju oraz miejsca w społecznym podziale pracy — wspólnot narodowych. Niezbędne byłoby ujęcie porównawcze. Wtedy „pedagogika wstydu” musiałaby ustąpić poważnej, naukowej dyskusji, a tym nikt nie wydaje się zainteresowany.

Okupacja hitlerowska w Polsce wyglądała subiektywnie inaczej w świadomości ludności żydowskiej, a inaczej w perspektywie ludności „aryjskiej”. Jak pisał Leszek Kołakowski (2009, s. 197-198), świadomość żydowska jest inna niż perspektywa nie-Żydów, i stanowi tylko część skomplikowanej prawdy. Jeżeli poważnie traktować subiektywne świadectwa ofiar jako materiał historyczny, to według świadectw Polaków, którzy we wrześniu 1939 roku znaleźli się pod okupacją 
„Kolektywizacja grzechu, niszczy moralne związki między ludźmi” (Wildavsky 1991, s. 228) ${ }^{30}$.

Jednocześnie „narodowcy” tworzą swój własny, zbudowany na kompleksie niższości, antyetos narodowy. W tej narracji naród polski jawi się jako ofiara własnych wad i błędów politycznych rządzących, a także spisku wrogich sąsiadów. Postulują budowę silnego państwa - co słuszne. Problem w tym, że w ich wizji silne państwo nie jest silne instytucjami i społecznym dla nich poparciem. Podstawą tej siły mają być scentralizowane, arbitralne rządy, a ich uzasadnieniem wrogość zewnętrznego i wewnętrznego otoczenia, mit „oblężonej twierdzy”. W ten sposób dąży się do integrowania społeczeństwa na patologicznych podstawach.

Stanowiska „internacjonalistyczne” oraz „narodowe” stały się narzędziem demobilizacji społeczeństwa obywatelskiego, któremu obie strony, choć z różnych powodów, nie ufają. Tym samym przyczyniły się do słabości konstytucyjnych podstaw III RP. Głębokie podziały polityczne, skoncentrowane wokół drugorzędnych dla przyszłości narodu kwestii, pozwalają uniknąć debaty dotyczącej sprawy zasadniczej: słabości instytucjonalnej państwa (zob. Kamiński 2014). Oba stanowiska łącznie powodują dezintegrację instytucji życia publicznego i rozkład społeczeństwa obywatelskiego; pierwsze niszczy kulturowe podstawy państwa; drugie - podważa wprost jego instytucje.

Celem tych rozważań było wykazanie, że $\mathrm{w}$ rozwoju polskiej tradycji narodowej wykształciły się wartości o charakterze uniwersalnym, które - choć nie zawsze respektowane - do dzisiaj w naszym społeczeństwie przetrwały, tworząc podstawę funkcjonowania społeczeństwa obywatelskiego. Bez takiej podstawy nie można sobie wyobrazić przyszłości liberalno-demokratycznego państwa, a przecież to państwa o tym ustroju dały początek procesom globalizacji. Niepokój o przyszłość Polski budzą „plemienne” podziały w trzonie intelektualno-politycznej elity. Pod jednym względem oba plemiona są sobie bliskie: nie proponując nic w zamian, oba niszczą najcenniejsze elementy narodowej tradycji.

\section{BIBLIOGRAFIA}

Bardach Juliusz, 1984, Początki sejmu, w: Historia sejmu polskiego: do schytku szlacheckiej Rzeczypospolitej, t. 1, Państwowe Wydawnictwo Naukowe, Warszawa.

Bermeo Nancy, 2003, Ordinary People in Extraordinary Times: The Citizenship and the Collapse of Democracy, Princeton University Press, Princeton.

sowiecką, Żydzi en mass cieszyli się na widok idących do niewoli żołnierzy polskich, współpracowali z sowieckim okupantem i denuncjowali swoich polskich sąsiadów. Tego typu informacje mogły wpłynąć na stosunek Polaków do Żydów pod okupacją niemiecką. A przecież ten obraz też odbiegał od rzeczywistości.

30 Podobnie, komentując doktrynę Jean-Paul Sartre'a, pisał Leszek Kołakowski (2009, s. 247): „[...] skoro jestem odpowiedzialny za cały świat, to za nic nie jestem odpowiedzialny". 
Bobrowski Tadeusz, 1979, Pamiętnik mojego życia, oprac. Stefan Kieniewicz, PIW, Warszawa.

Bryant Christopher G. A., 1997, Obywatelski naród, obywatelskie społeczeństwo, obywatelska religia, tłum. E. Woydyłło-Osiatyńska, w: Jerzy Szacki (wyb. i oprac.), Ani ksiażę, ani kupiec: obywatel, Znak-Fundacja im. Stefana Batorego, Kraków-Warszawa.

Bues Almut, 2010, Kształtowanie się monarchii polsko-litewskiej w XVI wieku, w: Richard Butterwick (red.), Rozkwit i upadek I Rzeczypospolitej, tłum. Daria Kuczyńska-Szymala, Bellona, Warszawa.

Butterwick Richard, 2010, Wprowadzenie, w: Richard Butterwick (red.), Rozkwit i upadek I Rzeczypospolitej, tłum. Daria Kuczyńska-Szymala, Bellona, Warszawa.

Bystroń Jan Stanisław, 1994, Dzieje obyczajów w dawnej Polsce: wiek XVI-XVIII, PIW, Warszawa.

Chałasiński Józef, 1946, Społeczna genealogia inteligencji polskiej, Czytelnik, Warszawa.

Chmielewski Piotr, 2016, Ćwierćwiecze polskiej transformacji: dlaczego tak powoli ksztattuje się nowy porzadek społeczny, w: Witold Morawski (red.), Wobec wyzwań jutra. Co myślą Polacy i jak działaja?, Wolters Kluwer, Warszawa.

Churchill Winston B., 1960, The Second World War: The Gathering Storm, vol. 1, London.

Conrad Joseph, 1965, Ze wspomnień, tłum. Aniela Zagórska, PIW, Warszawa.

Custine Astolphe de, 1995, Rosja w roku 1839, tłum. Paweł Hertz, PIW, Warszawa.

Czepulis-Rastenis Ryszarda, 1973, Klassa umystowa: Inteligencja polska Królestwa Polskiego 1832-1862, Książka i Wiedza, Warszawa.

Czepulis-Rastenis Ryszarda, 1976, Program badań dziejów inteligencji polskiej oraz jego zagadnienia metodologiczne, „Dzieje Najnowsze”, t. 8, nr 1.

Delsol Chantal, 2017, Nienawiść do świata: totalitaryzmy i ponowoczesność, tłum. Marek Chojnacki, Instytut Wydawniczy Pax, Warszawa.

Dzięgielewski Jan, 1993, „Stan szlachecki w życiu publicznym Rzeczypospolitej w pierwszym stuleciu po unii lubelskiej”, w: Anna Sucheni-Grabowska, Alicja Dybkowska (red.), Tradycje polityczne dawnej Polski, Editions Spotkania, Warszawa.

Ihnatowicz Ireneusz, Mączak Antoni, Ziętara Benedykt, Żarnowski Janusz, 2005, Społeczeństwo polskie od X do XX wieku, Książka i Wiedza, Warszawa (wyd. 5).

Jan Paweł II [Karol Wojtyła], 2005, Pamięć i tożsamość, Znak, Kraków.

Jedlicki Jerzy, 1996, Oblicza polskiego patriotyzmu (tezy do dyskusji), w: Państwo, społeczeństwo, cnoty obywatelskie, Zeszyty Fundacji MCRD, z. 11.

Judt Tony, 2013, Brzemię odpowiedzialności: Blum, Camus, Aron i francuski wiek dwudziesty, tłum. Michał Filipczuk, Wydawnictwo Krytyki Politycznej, Warszawa.

Kamiński Antoni Z., 1991, An Institutional Theory of Communist Regimes: Design, Function, and Breakdown, ICS Press, San Francisco.

Kamiński Antoni Z., 2014, Dezercja elit: Konsolidacja ustroju politycznego w pokomunistycznej Polsce, ISP PAN, Warszawa.

Kamiński Antoni Z., 2017, III RP. Między Redaktorem a Prezesem, „Rzeczy Wspólne”, \#24 (1), s. 84 $-97$.

Kiaupienė Jurate, 2010, Wielkie Księstwo Litewskie $i$ wielcy książęta litewscy w XVI wieku: refleksje nad litewskim narodem politycznym i unią lubelska, w: Richard Butterwick (red.), Rozkwit i upadek I Rzeczypospolitej, tłum. Daria Kuczyńska-Szymala, Bellona, Warszawa.

Kijowski Andrzej, 1984, O dobrym Naczelniku i niezłomnym Rycerzu, Wydawnictwo Literackie, Kraków. Kłoczowski Jerzy, 2002, Polska - Europa, Novus Orbis, Gdańsk.

Kołakowski Leszek, 2009, Czy Pan Bóg jest szczęśliwy i inne pytania, Znak, Kraków.

Korwin-Milewski Hipolit, 1930, Siedemdziesiąt lat wspomnień, Jan Jachowski — Księgarnia Uniwersytecka, Poznań.

Krasnodębski Zdzisław, 2003, Demokracja peryferii, słowo/obraz terytoria, Gdańsk.

Kuchowicz Zbigniew, 1975, Obyczaje staropolskie, Wydawnictwo Łódzkie, Łódź. 
Kurczewska Joanna, 2008, Trzy spojrzenia socjologiczne na inteligencje polska, w: Jan Kieniewicz (red.), Inteligencja, imperia, cywilizacje w XIX i XX wieku, Wydawnictwa Uniwersytetu Warszawskiego, Warszawa.

Lednicki Wacław, 1963, Pamiętniki, t. 1, Wydawnictwo B. Świderski, Londyn.

Malinowska Monika, 2008, Sytuacja kobiety w siedemnastowiecznej Francji i Polsce, Wydawnictwa Uniwersytetu Warszawskiego, Warszawa.

Marody Mirosława, 2014, Jednostka po nowoczesności. Perspektywa socjologiczna, Scholar, Warszawa.

Marshall T. H., 1950, Citizenship and Social Class and Other Essays, Cambridge University Press, London.

Melchior Małgorzata, 1983, Ethos Szarych Szeregów, „Etyka”, t. 20.

Miłosz Czesław, 1959, Rodzinna Europa, Instytut Literacki, Paryż.

Moltke Helmuth von, 1996 [1832], O Polsce, tłum. Gustaw Karpeles, Auditor, Warszawa.

Opaliński Edward, 2016, Społeczeństwo szlacheckie wobec Rzeczypospolitej Obojga Narodów w okresie 1572-1668: reakcja na spadek efektywności państwa, w: Wojciech Kriegseisen (red.), My i Oni: spoteczeństwo nowożytnej Rzeczypospolitej wobec państwa, IH PAN, Warszawa.

Ossowska Maria, 1986, Ethos rycerski i jego odmiany, Państwowe Wydawnictwo Naukowe, Warszawa. Ossowska Maria, 1992, Wzór demokraty: cnoty i wartości, Daimonion, Lublin.

Ossowski Stanisław, 1968, Ruchliwość społeczna jako wynik rewolucji społecznej, w: Stanisław Ossowski, Zagadnień struktury społecznej. Dzieła, t. 5, Państwowe Wydawnictwo Naukowe, Warszawa.

Pattee Howard H., 1973, Hierarchy Theory: The Challenge of Complex Systems, G. Braziller, New York.

Pawełczyńska Anna, 2004, Głowy hydry. O przewrotności wspótczesnego zła, Test, Lublin.

Pawełczyńska Anna, 2010, O istocie narodowej tożsamości. Polacy wobec zagrożeń, Polihymnia, Lublin.

Regulski Jerzy, 2001, Samorzad III Rzeczypospolitej. Koncepcje i realizacja, Wydawnictwo Naukowe PWN, Warszawa.

Rieff David, 2017, In Praise of Forgetting: Historical Memory and its Ironies, Yale University Press, New Haven-London.

Różycki Bartłomiej, Zima Amelie, 2017, Symboliczne metody przywracania pamięci w Europie: Polska, Hiszpania i inne przypadki odtwarzania symboli przeszłości, w: Andrzej Paczkowski (red.), Rozliczanie totalitarnej przeszłości: zbrodnie, kolaboracja i symbole przeszłości, ISP PAN, Warszawa.

Sadowski Zdzisław, 1964, Pieniądz a poczattki upadku Rzeczypospolitej w XVI wieku, Państwowe Wydawnictwo Naukowe, Warszawa.

Seredyka Jan, 1981, Sejm zawiedzionych nadziei, Wyższa Szkoła Pedagogiczna, Studia i monografie nr 72, Opole.

Shills Edward, 1997, The Virtue of Civility: Selected Essays on Liberalism, Tradition, and Civil Society, Liberty Fund, Indianapolis.

Słodkowska Inka, 2014, Komitety Obywatelskie 1989-1992. Rdzeń polskiej transformacji, ISP PAN, Warszawa.

Smolka Stanisław, 1907, Polityka Lubeckiego przed Powstaniem Listopadowym, t. 1 i 2, Nakładem Akademii Umiejętności, Kraków.

Sucheni-Grabowska Anna, 1993, Przeobrażenia ustrojowe od Kazimierza Wielkiego do Henryka Walezego, w: Anna Sucheni-Grabowska, Alicja Dybkowska (red.), Tradycje polityczne dawnej Polski, Editions Spotkania, Warszawa.

Szacki Jerzy, 1997, Wstęp. Powrót idei społeczeństwa obywatelskiego, w: Jerzy Szacki (wyb. i oprac.), Ani książę, ani kupiec: obywatel, Znak-Fundacja im. Stefana Batorego, Kraków-Warszawa.

Szacki Jerzy, 2011, Tradycja, Wydawnictwo Uniwersytetu Warszawskiego, Warszawa.

Tarnowski Stanisław, 2000, Pisarze polityczni XVI wieku, Ośrodek Myśli Politycznej-Księgarnia Akademicka, Kraków.

Tazbir Janusz, 1986, Myśl polska w nowożytnej kulturze europejskiej, Nasza Księgarnia, Warszawa.

Tazbir Janusz, 1997, Polska na zakrętach dziejów, Sic!, Warszawa. 
Tocqueville Alexis de, 1970, Dawny ustrój i rewolucja, tłum. Anna Wolska, Czytelnik, Warszawa. Walicki Andrzej, 2009, Naród, nacjonalizm, patriotyzm, Universitas, Kraków.

Weber Max, 2002, Gospodarka i społeczeństwo. Zarys socjologii rozumiejącej, tłum. Dorota Lachowska, Wydawnictwo Naukowe PWN, Warszawa.

Wereszczycki Henryk, 1987, Niewygasła przeszłość, Znak, Kraków.

Wildavsky Aaron, 1991, The Rise of Radical Egalitarianism, The American University Press, Washington, D.C.

Wyczański Andrzej, 1965, Polska rzecza pospolita szlachecką: 1454-1764, Państwowe Wydawnictwo Naukowe, Warszawa.

Zakrzewski Leszek S., 2004, Ethos rycerski w dawnej i wspótczesnej wojnie, Trio, Warszawa.

Znaniecki Florian, 1971, Nauki o kulturze, Państwowe Wydawnictwo Naukowe, Warszawa.

Znaniecki Florian, 1974, Ludzie teraźniejsi a cywilizacja przyszłości, Państwowe Wydawnictwo Naukowe, Warszawa.

Żaryn Małgorzata, 1993, Wieś w dawnej Polsce, w: Anna Sucheni-Grabowska, Alicja Dybkowska (red.), Tradycje polityczne dawnej Polski, Editions Spotkania, Warszawa.

\title{
THE ETHOS OF NOBILITY AND OF WELL-MANNERED PEOPLE: AN EPITAPH FOR POLISH INTELLIGENTSIA
}

\author{
Antoni Z. Kamiński \\ (Institute of Political Studies Polish Academy of Sciences)
}

\section{Summary}

The article is devoted to a critical analysis of current controversies concerning the Polish national identity, and the interpretation of the impact of nobles' democracy on the demise of the Polish Lithuanian Commonwealth. It considers the role of national identity as a factor influencing civic culture and, therefore, determining its usefulness in assuring the proper functioning of the constitutional order. The analysis assumes that (1) the current global order is the product of the emergence of nation-states; (2) that a nation-state cannot exist without civil society grounded in the concept of national identity and patriotism. Patriotism is opposed here to nationalism; similarly, cosmopolitism is opposed to internationalism. Patriotism and cosmopolitism are compatible and imply an open-minded, inclusive attitude to different national identities. Both nationalism with its focus on superiority of one's own nation, and internationalism-rejection of the nation-state in the name of an imaginary global, stateless community-are exclusive. These both exclusive postures present a threat to civil society.

\section{Key words / słowa kluczowe}

intelligentsia / inteligencja, nobles' democracy / demokracja szlachecka, modernization / modernizacja, oligarchy / oligarchia, ethos / etos, national identity / tożsamość narodowa, patriotism / patriotyzm, nationalism / nacjonalizm, cosmopolitism / kosmopolityzm, internationalism / internacjonalizm 